JEL Classification: F20, H73, O11, O33

\title{
CHARACTERISTICS OF INNOVATION AND INVESTMENT ASPECTS OF THE STATE REGULATION IN UKRAINE AND IN THE WORLD
}

\author{
Viacheslav Melnyk, Oksana Penkova
}

\begin{abstract}
The quality of the production machinery of Ukraine depends directly on the state and functioning of light industry. That is why the necessity of determining the prospects of light industry development in the conditions of the instability of the environment becomes urgent. The purpose of the article is to study the state of light industry in Ukraine and to determine the prospects to develop this type of economic activity in an unstable environment. The condition and peculiarities of light industry development in Ukraine under conditions of unstable external environment are considered. The factors that negatively influence light industry development are determined. Approaches to the prospects of light industry development on the way of Ukraine's integration into the EU are outlined. Light industry is a very promising industry. The main perspectives, in case of which the light industry of Ukraine would return the lost power, could be attributed to: improvement of the tax system; the organization of control over the use of working capital, the introduction of preferential lending to enterprises for the purchase of raw materials, which is not enough in Ukraine, the modernization of general production, the development of a new kind of goods; stimulating the development of its own raw material base of light industry; introduction of scientific and technological progress in light industry of Ukraine; improvement of the tariff-and-tariff regulation of the system of protection of the domestic commodity producer; expansion of the assortment of goods for different segments of the population; creation of conditions for the development of civilized channels of retail sales of goods; promotion of joint ventures, mergers of enterprises in the technological chain; stimulating the development of small enterprises for the production of clothing, footwear, and other consumer goods; improvement of working conditions and protection of the rights of employees of light industry enterprises.
\end{abstract}

Keywords: state, innovations, development, policy, experience, economic, technologies, competiveness, strategy.

\section{УДК 330.341.1:338.24(477)]:330(419) \\ ХАРАКТЕРИСТИКА ІННОВАЦІЙНО-ІНВЕСТИЦИЙНИХ АСПЕКТІВ ДЕРЖАВНОГО РЕГУЛЮВАННЯ В УКРАЇНI ТА СВІТІ}

\author{
Мельник В. В., Пенькова О. Г.
}

Анотація. Сучасна логіка інноваційного розвитку змінюється від позицій невтручання держави до активного державного стимулювання інноваційної діяльності на умовах державноприватного партнерства. Державному регулюванню притаманний постійний пошук оптимального співвідношення ринкової та державної складових. Поєднання цілей регіональної політики з іншими пріоритетами в єдину державну стратегію - мета кожної демократичної держави. Створення механізму взаємодії та партнерства влади, бізнесу й громадськості світовий досвід, втілений в життя інститутами Свропейського Союзу, інтеграцію до якого проголошено пріоритетним завданням української державної політики. Поступова трансформація полягає на поетапних змінах і плавною адаптацією до цих змін. Натомість раптова трансформація базується на швидкій зміні старої влади і правопорядків, будові нової системи і іï інтеграції в державні процеси.

Ключові слова: держава, інновації, розвиток, політика, досвід, технології, економіка, конкуренція, стратегія. 
Problem statement. Ensuring sustainable development on the innovative basis of the domestic economy is impossible without developing an effective innovation and investment system. According to many researchers, the state should become the key player in the transformational processes, including the formation of the institutional conditions for innovation and investment activity, at the transitional stage of the economic development. In addition, the necessity of state intervention in the economy was also substantiated by $D$. Keynes in the 1930's, since it is proved that the market mechanism of self-regulation is not able to overcome particular problems of the economic development, such as cyclicality, unemployment, etc.

J. M. Keynes and the post-Keynesian representatives believe that monitoring the situation of market parameters is one of the functions of the state (government). Any non-equilibrium action must be registered and based on built-in stabilizers aimed at a trajectory of balanced equilibrium growth. So, the government affects one or another segment of the market [20, p. 24].

The above thesis is confirmed by V. Polokhalo, Chairman of the Supreme Council of Ukraine, Committee on Science and Education. He noted that for Ukraine the problem of the formation of the innovation system is not that someone does not understand or deny innovation usefulness, but that the direct transfer of neoclassical models that have been developed in the highly developed countries of the world and are adequate only to the conditions in transition economy countries (for example, Ukraine) does not achieve the expected results. Modern logic of the innovation development is changing from the point of view of non-interference of the state to active public stimulation of innovation activity under the conditions of public-private partnership. State regulation is fundamentally needed for the development of even the most liberal model of the economy. Roosevelt, Erhart and Thatcher brought their countries out of a crisis with a strong state power and today this is also the case in many countries [16].

Actual scientific research and issue analysis. The need for a clear state policy in the field of innovation and investment is emphasized by foreign and domestic scientists. The issues of scientific and methodological foundations of state regulation of investment and innovation activity are investigated in the works of V. Heits, M. Danko, L. Zhalilo, A. Kinakh, V. Martynenko, A. Muzychenko, M. Krupka, B. Santo, A. Utkin and others.

Research goals. It is extremely important to investigate the mechanisms of state regulation of innovation and investment activity and the conditions for the formation and implementation of the state's innovation and investment policy.

Statement of basic materials. State regulation entities are central, regional, municipal or communal management bodies. There are the following types of state regulation:

- it is full state monopoly in the management of the economy. It was characteristic for the USSR and the countries of the socialist community but it is still preserved in some post-communist states;

- they are various options for a combination of market and government regulators. They are implemented in the "Japanese", "Swedish" models, in the model of socially oriented market economy of Germany, Austria and in the "Chinese" version of development;

- it is extreme liberalism which recognizes only the conditions of unlimited private enterprise. It is mainly peculiar to the USA [4, p. 77]. 
State regulation is characterized by a flow chart of the state regulation of the inconstant search for an optimal ratio of mar- vestment process is proposed (Fig. 1) [18]. ket and state components $[9,12]$. That is, a

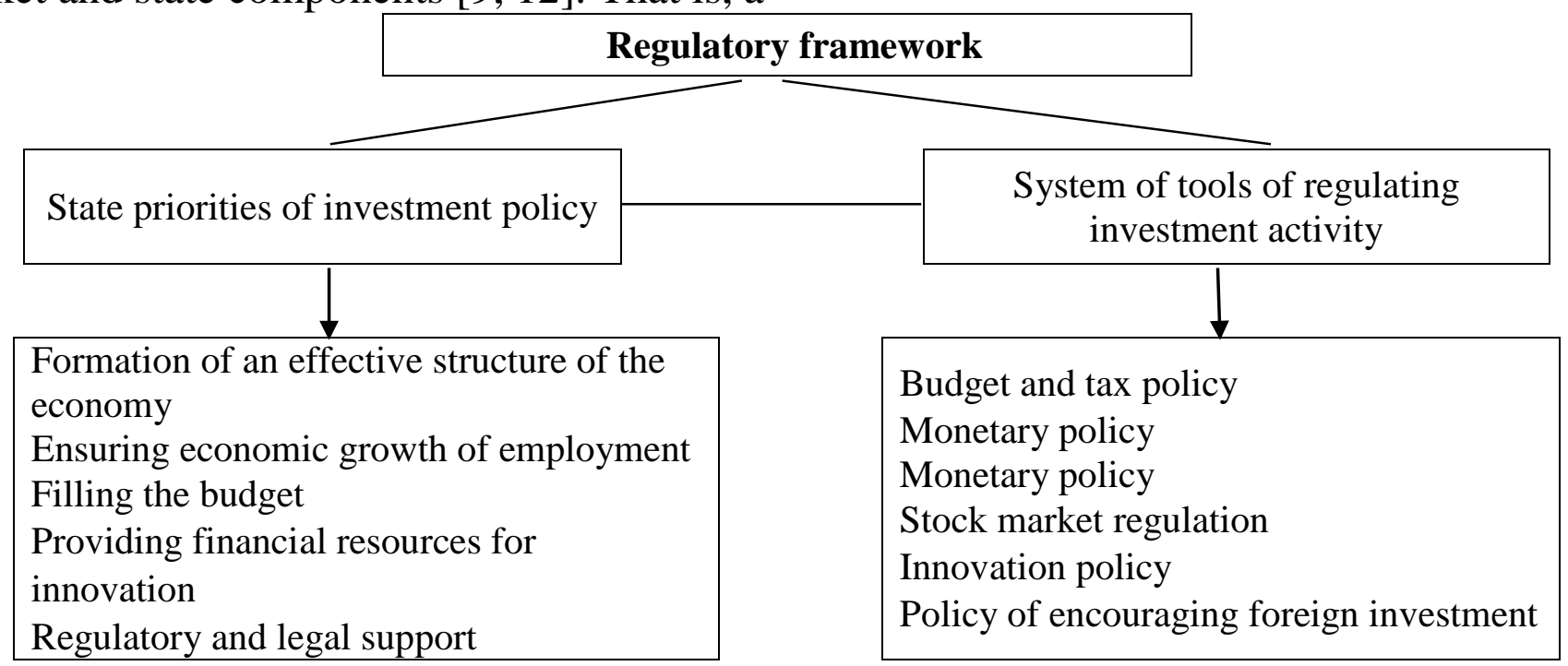

Source: [18].

Perhaps in Ukraine, the scope of state regulation may be much wider than in traditionally market countries. However, this does not mean that you can reject foreign experience. On the contrary, it needs to be comprehensively studied and, at the same time, certain conclusions should be made. The combination of regional policy objectives with other priorities in a single state strategy is the goal of every democratic state. Developing a mechanism for interaction and partnership between government, business and public is the world experience, implemented by the institutes of the European Union. Its integration has been declared a priority task of the Ukrainian state policy [5, p.103].

Ukraine, as well as a number of other countries in Europe and Asia, is at the beginning of reforming economic structures. The functioning of the state regulation mechanism is a prerequisite for Ukraine for a successful reforming of the market economy system. Perhaps in Ukraine, the scope of state regulation may be much wider than in traditionally market countries. However, this does not mean that you can reject foreign experience. On the contrary, it needs to be comprehensively studied and, at the same time, certain conclusions should be made. Our country does not have enough own experience in the formation and use of a market system. So, it is expedient to study and use the practice of state regulation of developed countries. Studying the experience will avoid repeating many mistakes in the development of the economy [22, p. 56].

In accordance with international commitments and the strategic goal of further European integration, Ukraine will continue transformation on the basis of strengthening democracy, rule of law, respect for human rights, the principle of the separation of powers and independence of the judiciary and democratic elections in accordance with the norms and standards of the OSCE and the Council of Europe. A man, his life and health, honor and dignity, inviolability and security are recognized in Ukraine as the highest social value [8]. 
A characteristic feature of the European Union policy in the 1990's and the beginning of the XXI century is to increase attention to the improvement of national innovation systems and to increase the role of human and intellectual capital as main sources of the economic and social development [10].

This orientation is based on a number of conceptual documents of the EU which have been developed in recent years and are of great practical importance. Among them, the most significant documents are the report of the EU Commission "Towards the European Research Area", the materials of the sessions of the European Union in Lisbon and Barcelona and the Sixth Framework Program for Research in the EU. They served as the start of active actions to deepen the integration of the innovation cycle in the region, especially its initial stage (the education and training system) and, ultimately, the formation of the innovation system across the European region [1].

State regulation is necessary for the successful transformation of the results of scientific and technological activities into an innovative product as a market economy is not always able to do it in view of the high cost and the long payback period of innovative projects. The state regulation of IP commercialization refers to a set of actions and measures implemented by the state through relevant authorities, regulations and state target programs in order to identify main economic processes for obtaining revenues from private and stateowned intellectual property objects. Consequently, such regulation actually provides for the promotion of the creation of rights to intangible assets that will be in the interests of all interested groups of economic entities. Such actions and measures form a state-stimulating regulatory policy for IP organizational and economic relations [14].

Another trend of the last decade is that private sector spending on $\mathrm{R} \& \mathrm{D}$ both in the European region and in other developed regions of the world is largely "fed up" with the venture capital market which tends to expand [15].

Support for small and medium-sized enterprises is particularly important as the experience of the United States, Canada and Europe shows that about $80 \%$ of new jobs are created due to the growth of existing businesses in the city. Moreover, the recent experience of Central Europe proves that cities that are too relying on one large employer or one industry are exposed to the economic risk. A balanced and healthy economy should include a number of different small (up to 50 employees) and medium (up to 250 employees) enterprises, including trade, commercial and service enterprises, to meet the needs of citizens and diversify the economy [7].

Gradual transformation consists of phased changes and smooth adaptation to these changes. Instead, the sudden transformation is based on the rapid change of the old power, law and order, the structure of the new system and its integration into state processes.

T. Mikhalsky has identified reforms that apply to all sectors of the economy. This is primarily a reform in the large-scale sector where industry and agriculture need to be restructured and ruined by the ruling elite; changes in the financial sector, namely, creation of a modern banking sector and introduction of new rules of cooperation with other countries; changes in administrative and legal systems, for example, creation of a new tax system [13]. 
So, an analysis of the dynamics of post-communist transformations in Ukraine and Poland shows that states can develop for a long time in practically opposite directions, even similar in the cultural and historical aspect. In the context of the neighborhood with Russia, it can be stated that the geopolitical situation has a significant impact on domestic affairs. In particular, the Ukrainian realities indicate that the Russian direct influence may worsen the situation in the country and the proximity of Poland to the EU developed countries will be able to stimulate social and economic development. Today, the experience of other countries in reforming social relations, economy and conducting administrative reform is especially valuable to Ukraine [11].

The Ukrainian-Polish relations of a new format began on October 1, 1991, with the signing of an agreement between the Governments of Ukraine and the Republic of Poland on trade and economic cooperation [21]. On December 18, the same year, on the initiative of the Polish government in Zamost city, there was a regional meeting of representatives of the border regions of Ukraine and the provinces of Poland [6, p. 335-337].

Poland chose the path of a sudden transformation which led to the transition from a planned economy to a market one and changed the whole political system and socio-economic structure. The sequence of changes in the sudden transformation by L. Baltserovich is as follows: macroeconomic stabilization, microeconomic liberalization (which consists in the elimination of restrictions imposed by the authorities on entrepreneurial activity, elimination of price control and restrictions on foreign trade), as well as radical reconstruction which task is privatization of state-owned enterprises, regionalization of state administrations, the reform of the tax system and creation of new institutions such as the stock exchange [3].

Table 1

Types of incentives to stimulate investment activity in Poland

\begin{tabular}{|c|c|c|}
\hline Type of incentives & Maximum support & $\begin{array}{l}\text { Responsible } \\
\text { authority }\end{array}$ \\
\hline \multicolumn{3}{|c|}{ Incentives in the field of taxation } \\
\hline $\begin{array}{l}\text { Income tax for legal (physical) } \\
\text { persons for activities in a special } \\
\text { economic zone }\end{array}$ & $\begin{array}{l}-50 \% \text { of investment costs } \\
-50 \% \text { of biennial expenditures for newly recruited } \\
\text { workers } \\
-40 \% \text { in six voivodships } \\
-30 \% \text { for Warsaw and Mazowieckie Voivodeship }\end{array}$ & $\begin{array}{l}\text { - } \text { Administration } \\
\text { of a special } \\
\text { economic zone }\end{array}$ \\
\hline Real estate tax & $\begin{array}{l}\text { - Ability to reduce the tax rate or exemption from } \\
\text { payment }\end{array}$ & \multirow{2}{*}{$\begin{array}{l}- \text { Council of a } \\
\text { gmina } \\
\text { village) }\end{array}$} \\
\hline Transport tax & $\begin{array}{l}\text { - Ability to reduce the tax rate until the full } \\
\text { exemption from payment }\end{array}$ & \\
\hline \multicolumn{3}{|c|}{ Financial support for investment from the state budget } \\
\hline Investment grants & - Up to $50 \%$ of the maximum level of state aid & \multirow{4}{*}{$\begin{array}{l}- \text { Ministry of } \\
\text { Economy, Labor } \\
\text { and Social Policy }\end{array}$} \\
\hline Employment grants & $\begin{array}{l}\text { - Up to } 4000 \text { euros for one created job but no more } \\
\text { than } 50 \% \text { of biennial payouts for new employees }\end{array}$ & \\
\hline Retraining grants & - Up to 1150 euros per employee & \\
\hline $\begin{array}{l}\text { Grants for infrastructure } \\
\text { development of a city or a village } \\
\text { in connection with the investment }\end{array}$ & - Up to $50 \%$ of investment costs & \\
\hline
\end{tabular}

Source: [7]. 
Table 1 shows the types of incentives that are used in Poland to stimulate investment activity with Ukraine and other countries [17]. The World Bank data on Poland's foreign direct investments shows that the types of incentives are effective. In 2009, direct foreign investments of Poland amounted to about \$14388 million, in 2010 it was $\$ 1707$ million and in $2011-\$ 17357$ million [19].

Conclusions and directions for future research. However, there is no doubt that the main factor in the success of posttotalitarian transformation is the level of development of civil society. An example of Poland proves that the key role in this process lies with the positive will of the people themselves who are able to unite and ultimately achieve significant economic success, for the sake of development. Such an association involves establishing constructive cooperation between the public sector and the public. Otherwise, there is no reason to hope to overcome negative trends in the development and improvement of the social and economic situation in Ukraine.

\section{References}

1. Arnold, E., Clark, J. and Bussillet, S. (2004) Impacts of the swedish competence centres programme 1995-2003, Swedish Agency for Innovation Systems, Stockholm, Sweden.

2. Bąk, M. (2006), Europa Środkowa i Wschodnia wobec wyzwania transformacyjnego, Wydawnictwo Uniwersytetu Gdańskiego, Gdansk, Poland.

3. Balcerowicz, L. (1997), Socjalizm, kapitalizm, transformacja, szkice z przełomu epok, Wydawnictwo Naukowe PWN, Warsaw, Poland.

4. Bashlai, S. V. and Shumkova, O. V. (2006), "The role of the banking system in the development of the financial market of Ukraine", Problems and prospects of development of the banking system of Ukraine, vol. 5, pp. 33-36.

5. Berehovoi, T. A. (2011), "Experience of regional development of the EU and its projection to Ukraine", Actual problems of public administration, no. 2(26), pp. 103-107.

6. Biletska, H. M. (2007), "Regionalization is the EU prospects", Yevropeiski intehratsiini protsesy $i$ transkordonne spivrobitnytstvo [European Integration Processes and Cross-Border Cooperation], Tezy dopovidei IV Mizhnarodnoi naukovo-praktychnoi konferentsii [Theses of reports of IV International scientific-practical conference], Lutsk, Ukraine, May 17-18, 2007, pp. 335-338.

7. Mier, R. (ed.) and Giloth R. (1993), "Cooperative leadership for community problem solving in Social justice and local development policy, Newbuiy Park CA, Sage, pp. 165-181.

8. The Verkhovna Rada of Ukraine (1996), The Constitution of Ukraine, Parliamentary Publishing House, Kyiv, Ukraine.

9. Kriuchkova, I. V. and Popelniukhov, R. V. (2010), "Theoretical and methodological aspects of state regulation of investment policy as an important factor of economic growth", Bulletin of Khmelnytsky National University, no. 1, vol. 1, pp. 298-301.

10. Kuzin, D. (1993). "Industrial policy of developed countries: goals, tools, assessments", Voprosy jekonomiki, no. 91, pp. 133-144.

11. Lesechko, M. and Chemerys, A. (2001), "Administrative reform: Polish experience and Ukrainian realities", Actual problems of public administration, no. 5, pp. 92-105.

12. Meher, M. (2010) "Direct foreign investment and their impact on the regional economy in Ukraine", Scientific Bulletin of NLTU of Ukraine, issue 20(5), pp. 227-235.

13. Mikhalsky, T. A. (ed.) (2006), "Geographical approach to the transformation process in European post-communist countries" in The Geographical Aspects of the Transformation Process in Central and East-Central Europe, Wydawnictwo Bernardinium, Gdynia-Pelplin, Poland, pp. 726. 
14. Nevinchanyi, I. S. (2011), "State regulation of intellectual property in Ukraine", Ph.D. Thesis, Economy and national economy administration, Academy of municipal administration, Kyiv, Ukraine.

15. North, D. (2000), Institutions, institutional change and functioning of the economy, Osnovy, Kyiv, Ukraine.

16. The Verkhovna Rada of Ukraine (2010), Parliamentary hearings "Strategy of innovative development of Ukraine in 2010-2020 in the context of globalization challenges", available at: http://zakon0.rada.gov.ua/laws/show/2632-17 (Accessed 22 May 2018).

17. Official site of Polish Agency for Information and Foreign Investments, available at: http://www.paiz.gov.pl/index. (Accessed 22 May 2018).

18. Reznik, N. P. (2008), "Foreign investment experience in the agricultural industrial complex", Kul'tura narodov Prichernomor'ja, no. 147, pp. 77-80.

19. Official site of The World Bank (2018), Foreign direct investment, net inflows (BoP, current US\$), available at: http://data.worldbank.org/indicator/BX.KLT.DINV.CD.WD (Accessed 22 May 2018).

20. Stechenko, D. M. (2000), Upravlinnia rehionalnym rozvytkom [Regional development management], Vyshcha shkola, Kyiv, Ukraine.

21. Ministry of Foreign Affairs of Ukraine (1991), Agreement between the Government of Ukraine and the Government of the Republic of Poland on Trade and Economic Cooperation, available at: http://www.mfa.gov.ua. (Accessed 22 May 2018).

22. Ukraina. Finansovyi sektor ta ekonomika: nova stratehiia reform [Ukraine. Financial sector and economy: a new reform strategy], Materialy konferentsii [Materials of the Conference], June 2223, 2006, $124 \mathrm{p}$.

\section{Literature}

1. Arnold, E. Impacts of the Swedish competence centres programme 1995-2003 / E. Arnold, J. Clark, S. Bussillet ; Swedish Agency for Innovation Systems. - Stockholm, 2004. -173 p.

2. Bąk, M. Europa Środkowa i Wschodnia wobec wyzwania transformacyjnego / M. Bąk. - Gdańsk : Wydawnictwo Uniwersytetu Gdańskiego. - 2006. - 225 p.

3. Balcerowicz, L. Socjalizm, kapitalizm, transformacja, szkice z przełomu epok / L. Balcerowicz. - Warszawa : Wydawnictwo Naukowe PWN. - 1997. -176 p.

4. Башлай, С. В. Роль банківської системи в розвитку фінансового ринку України / С. В. Башлай, О. В. Шумкова // Проблеми і перспективи розвитку банківської системи України : зб. наук. праць.- Суми : УАБС НБУ, - 2006. - Т. 5. - С. 33-36.

5. Береговой, Т. А. Досвід регіонального розвитку ЄС та його проекція на Україну / Т. А. Береговой //Актуальні проблеми державного управління : зб. наук. пр. ОРІДУ. - 2011. - Вип. 2(26). - C. 103-107.

6. Білецька, Г. М. «Регіоналізація»- перспективи СС / Г. М. Білецька // Європейські інтеграційні процеси і транскордонне співробітництво : тези доповідей IV Міжнар. наук.-практ. конф. (17-18 травня 2007 р., м. Луцьк). - Луцьк : РВВ «Вежа» ВДУ ім. Лесі Українки. 2007. - C. 335-338.

7. Mier, R. Cooperative leadership for community problem solving / R. Mier (ed.), R. Giloth // Social justice and local development policy. - Newbuiy Park CA; Sage, 1993. - P. 165-181.

8. Конституція України : прийнята на п’ятій сесії Верховної Ради України 28 черв. 1996 р. ; зі змінами згідно із Законом України від 8 груд. 2004 р. № 2222. - К. : Парламентське видво. $-2005 .-98$ с.

9. Крючкова, І. В. Теоретико-методологічні аспекти державного регулювання інвестиційної політики як важливого фактора економічного зростання / І. В. Крючкова, Р. В. Попельнюхов // Вісник Хмельницького національного університету. - 2010. - № 1. - Т. 2. - С. 298 301. 
10. Кузин, Д. Промышленная политика развитых стран: цели, инструменты, оценки / Д. Кузин // Вопросы экономики. - 1993. - № 91. - С. 133-144.

11. Лесечко, М. Адміністративна реформа: досвід Польщі та українські реалії / М. Лесечко, А. Чемерис // Актуальні проблеми державного управління : зб. наук. пр. ОФ УАДУ. 2001. - № 5. - C. 92-105.

12. Мегер, М. Прямі іноземні інвестиції та їхній вплив на регіональну економіку в Україні / М. Мегер // Науковий вісник НЛТУ України. - 2010. - Вип. 20.5. - С. 227-235.

13. Michalski, T. A Geographical approach to the transformation process in European post-communist countries // The geographical aspects of the transformation process in Central and EastCentral Europe / T. Michalski (red.). - Gdynia-Pelplin : Wydawnictwo "Bernardinium", 2006. S. 7-26.

14. Невінчаний, I. С. Державне регулювання інтелектуальної власності в Україні / I. С. Невінчаний : автореф. дис. ... канд. екон. наук : спец. 08.00.03 - економіка та управління національним господарством. - К., - 2011. - 20 с.

15. Норт, Д. Інституції, інституційна зміна та функціонування економіки / Даглас Норт ; пер. 3 англ. І. Дзюб. - К. : Основи, $-2000 .-198$ с.

16. Стратегія інноваційного розвитку України на 2010-2020 роки в умовах глобалізаційних викликів / парламентські слухання. - [Електронний ресурс]. - Режим доступу : http://www.rada.gov.ua/zakon/new/par_sl/index.htm.

17. Польське агентство інформації і іноземних інвестицій. - [Електронний ресурс]. - Режим доступу : http://www.paiz.gov.pl/index.

18. Резнік, Н. П. Зарубіжний досвід інвестування в агропромисловий комплекс / Н. П. Резнік // Культура народов Причерноморья. - 2008. - № 147. - С. 77-80.

19. Foreign direct investment, net inflows (BoP, current US\$) [Електронний ресурс] / Офіційний сайт Світового Банку. http://data.worldbank.org/indicator/BX.KLT.DINV.CD.WD.

20. Стеченко, Д. М. Управління регіональним розвитком : навч. посіб. / Д. М. Стеченко. - К. : Вища шк., 2000. - 223 с.

21. Угода між Урядом України та Урядом Республіки Польща про торгівлю та економічне співробітництво від 01.10.1991 p. // Міністерство закордонних справ. Угода. Міжнародні договори Ф.-ugod d32. - К., 1991. - С. 1-4. - [Електронний ресурс]. - Режим доступу : http://www.mfa.gov.ua.

22. Україна. Фінансовий сектор та економіка: нова стратегія реформ : матеріали конф. 22-23 червня 2006 р. - К. : Козаки, 2006. - 124 с.

\section{Бібліографічний опис для цитування:}

Melnik V. V. Characteristics of innovation and investment aspects of the state regulation in Ukraine and in the world / V. V. Melnik, O. H. Penkova // Науковий журнал «Економічні горизонти». - 2018. - № 2(5). - С. 20-27. 